\title{
Article
}

\section{'My Life is Like a Movie' \\ Making a Fiction Film as a Route to Knowledge Production on Gang Political Performances in Goma, DR Congo}

\author{
Maarten Hendriks \\ Ghent University
}

\begin{abstract}
My life is like a movie' is a sentence that often surfaced during my fieldwork on gangs engaged in everyday policing in the city of Goma (Democratic Republic of Congo); referring to the martial arts and action movies they like to watch. For this article, I will reflect on how during my ethnographic research I ended up making the fiction film Street Life together with the Congolese filmmaker TD Jack, the gang leader Alino and his group Rich Gang. The paper explores the making of Street Life as a route to knowledge production on the political performances of gangs seeking to carve out a space for themselves in Goma's urban policing environment. Broadly, two issues are dealt with. Firstly, I analyze how gangs' everyday political performances are re-enacted and actively mirrored in the film. Secondly, I reflect on how making a fiction with gangs changed my way of dealing with ethnography: in terms of method, my positionality in the field, and ethnographic representation. The paper is also a call for taking the visual and by extension other senses - more seriously. Not just by writing about sensory experiences, but by incorporating them in our academic work. Sometimes it is better to just let people see it!
\end{abstract}

Keywords gangs, everyday policing, visual ethnography, participatory video, ethnofiction, Goma, DR Congo

Goma, the provincial capital of North Kivu located at the border with Rwanda, finds itself at the very heart of the protracted armed conflict that has roiled the eastern provinces of the Democratic Republic of Congo (hereafter Congo) since the early nineties. Today, the city counts some 1,000,000 inhabitants. Although the city has been taken over by rebel groups thrice since the start of the First Congo War, today it finds itself under the firm control of the central government. ${ }^{22}$ In the framework of my $\mathrm{PhD}$ research, I ethnographically ${ }^{23}$ focus on groups of gangs - usually consisting of around 8-15 male youths - that transform themselves into ambiguous 'everyday policing actors' (Buur and Jensen 2004; Jensen 2008). Through policing commercial hotspots in Goma's popular neighborhoods at daytime, these groups (seek to) carve out a political space for themselves. Writing about similar groups in Mozambique, Kyed conceptualized such actors as 'street authorities', referring to a 'style of politics that relies on the capacity for swift direct actions, often through violent means, to create

22 For a good ethnography on processes of urbanization and conflict in the city of Goma, see the work of Karen Büscher (2011).

${ }^{23}$ Between 2015 and 2019, I carried out 16 months of ethnographic fieldwork in Goma. 
order in the streets (Kyed 2018, 19). More specifically, the focus of my research is on the so-called Anti-gang and other groups of gangs that work for ACCO (the Association of Congolese Drivers). The Antigang's core mission is 'protecting' tradespeople. In return for their 'protection' they ask a weekly fee of $200 \mathrm{FC}(+/-0,20 €)$ per shop, parasol or ambulant vendor operating in their territory. Gangs working for ACCO focus on 'bringing order' to taxi-bus stations, imposing a (ACCO) tax of 200-300FC on drivers who stop there. What they have in common is that they claim to protect the population against the crime and violence of the maibobo (street children in Kiswahili) and other gangs in the neighborhoods. People can call on them when someone steals a personal item such as a cellphone, or when they are threatened by maibobo or gangs. For a small fee, the Anti-gang will try to retrieve their phone, or deter the maibobo or gang that is causing trouble. Moreover - especially in the case of the Anti-gang - they carry out little jobs for the police, intelligence services, municipal authorities and even the army: for example, looking for wanted persons, evicting pirate markets, or providing muscle at public demonstrations (like the recent protests against Kabila in the run-up to the elections). They claim to be up for the task for two main reasons. Firstly, they are sportifs, a term used to refer to people trained in the martial arts. Only lightly armed with selfmade nunchuks, they claim to be much more agile than police officers carrying heavy machine guns. Secondly, they are gangs themselves. Therefore, they are familiar with and frequent the same ghettos (places where one can smoke weed and drink strong liquor) as the other gangs. Furthermore, as gangs and batoto ya Goma (children of Goma) they know its streets and corners like the backs of their hands. 24

I deliberately italicize the word 'gangs', as I am referring to its emic understanding. Obviously borrowed from the English term 'gang' (phonemically: /gæy/), 'gang' in Goma is pronounced with a French accent (phonemically: /gay/) and given a somewhat different meaning. Rather than denoting a 'group' of youths involved in illicit behavior, it refers to a person who is 'gang' or has 'gang' qualities. These qualities are centered around 'toughness' - in both a positive and negative sense. The term gang is mostly used to refer to marginalized youth or the tough guys of the neighborhood who smoke weed, drink strong liquor, and do not shy away from anything or anyone in order to get what they want. Like the maibobo, gangs do not enjoy a good reputation and are often blamed for much of the everyday crime and violence in the city such as theft, robbery and extortion.

Describing past and present events in their lives to me, gangs often dramatically declared: 'My life is like a movie' and 'we are living movies'. This article is about how eventually, on their demand, this led us to realize the movie Street Life, a fiction film on gangs, acted by gangs. I will reflect on how the making of Street Life, which started as an ethnographic experiment on the side, turned into a 'route to knowledge production' (Pink 2013) on the political performance of gangs carving out a space for themselves as 'street authorities'.

To some extent, the making of the film Street Life bears a resemblance to the idea behind the film Moi un Noir (1958) by the influential scholar and filmmaker Jean Rouch. Having

${ }^{24}$ For a more thorough analysis of gang and anti-gang practices and politics read 'The politics of everyday policing in Goma: the case of the Anti-gang' (Hendriks 2018). 


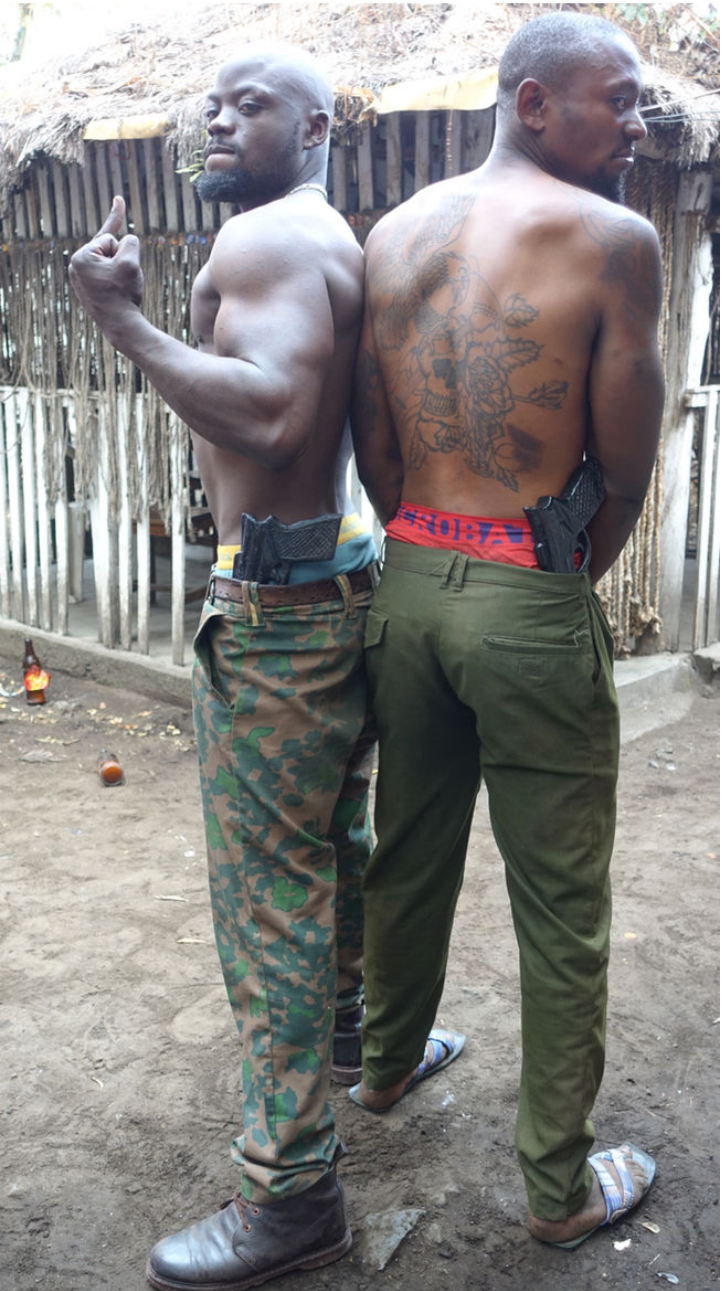

The good and bad guy of Street Life on the set, 06/07/2017. made films like Moi un Noir, Jaguar, Petit à petit and Cocorico Monsieur Poulet, Jean Rouch is considered the spiritual father of what others have later dubbed 'ethnofiction'. Stoller (1992, 143) defines these films as 'stories based upon laboriously researched and carefully analyzed ethnography', capturing the 'texture of an event' and the 'ethos of lived experience'. Moi un Noir, telling the stories of young migrants in Abidjan, is introduced by a brief commentary voice over of Jean Rouch recounting: 'For six months, I went around with a small group of young immigrants to Treichville, a suburb of Abidjan. I suggested to them making a film in which they would play their own roles, where they would have the right to do and say anything. That is how we came to improvise this film' (Jean Rouch, 1958 in Loizos, 1993, p. 50). Granting research participants the power to dictate and play their own roles was also the starting point for Street Life. Although we did work out a preliminary script, on the set there was much room for improvised acting.

On Congo, Filip De Boeck's documentary Cemetery State is a good example of how the medium of film is exceptionally well suited to represent ethnographic knowledge of performative and aesthetic aspects of social life. It shows how certain youths in Kinshasa who blame older generations for their living conditions, confiscate their deceased age-mates' coffins as a form of social critique - seizing them from family members while performing unruly dances and singing songs with violent lyrics (De Boeck 2014). Staying with Kinshasa, the way Katrien Pype methodologically engaged with the medium of 'film' is also worth mentioning here. Studying religion, media and gender in Kinshasa, she went as far as becoming an actress in Pentecostal television shows. Her participation as an actress, she writes, 'offered me a privileged vantage point from which to observe the production of the teleserials and also gave me a public identity. From that moment on, I came to be known as "Caleb's white girl" (Pype 2012, 21). In this special issue, Tessa Boeykens (2019) relates how returnees mobilized her in post-conflict Guatemala to 'make their history', by co-creating 'a documentary about their past and present struggle'. This article is epistemologically informed by our many discussions and her fresh approach to participatory filmmaking as a method. 
Broadly, this article deals with two connected issues. Firstly, the analyses of the everyday political performances of gangs, re-enacted in Street Life. Secondly, the implications of making a fiction film for ethnographic purposes: in terms of method, my positionality in the field and ethnographic representation. The first section tells the story of how we came to make this film. The second section deals theoretically and epistemologically with the concept of (political) performance. The third section zooms in on the movie Street Life itself, elaborating on how the film mirrors kigang (the style of being gang) everyday political performance. To conclude, the fourth section ethnographically reflects on the making of Street Life and how it changed my way of engaging with ethnography.

\section{Going Visual: From Living Films to Making One}

Coming back from my first exploratory two-month fieldwork period, I found myself sitting behind my desk trying to translate my first bits of observations and interviews into the format of an academic article. Two initial months of fieldwork are not much to go on for writing an article and I was writing very slowly. But this was only part of my frustration. 'You need to see it' (to better understand it) was a thought that constantly crossed my mind. 'Each culture, each person within it, uses the entire sensory repertoire to convey messages' (Turner 1982, 9). To fully understand how gangs in Goma realize themselves as street authorities, one should take into account their facial expressions, bodily gestures, the way they move, talk, etc. If they are living movies like they say, why then produce knowledge on the matter that reduces experiences to text, and observations to words?

With this in mind, on my next field visit, I handed out some second-hand cameras and smartphones to gangs. I did not give the receivers any directions on what to do with them, but asked if we could regularly discuss the images that they registered. However, the real turning point for my research going visual came about due to maître Patient, a leader of a group of Anti-gangs operating in and around the neighborhood of Katindo. One afternoon in March 2016, walking with him and six gangs to their base, he asked me: 'Martin, can't we make a film? A fiction film on our lives as sportifs and gangs in Goma?'25 He told me that he and his friends had already written a script. The whole group immediately became excited about the idea, fantasizing out loud about how they would become stars of their own action movie.

I said yes for a number of intuitive reasons. When they are narrating past events to each other - for example fights with other gangs, encounters with the police, their time working in the mines or locked up in prison - these youths dramatize their own lives. 'My life is like a movie' or 'I have lived a lot of movies' are sentences that arise repeatedly. 'It was like in this movie ...', after which they start to interpret their everyday events through the martial arts and action movies they like to watch. In fact, much as the Western genre served as an imaginary for the bill movement in colonial Kinshasa of the fifties, the martial arts genre represented by Bruce Lee, Jean Claude van Damme, Jet Lee, Jim Morris etc., underpins the imaginary of sportifs and gangs in Goma today (Olander n.d.). They are often trained in more than one discipline of martial arts, the techniques of which they learn from watching these movies. The leader of a gang bears

25 Informal conversation Patient, Goma, 20/03/2016. 


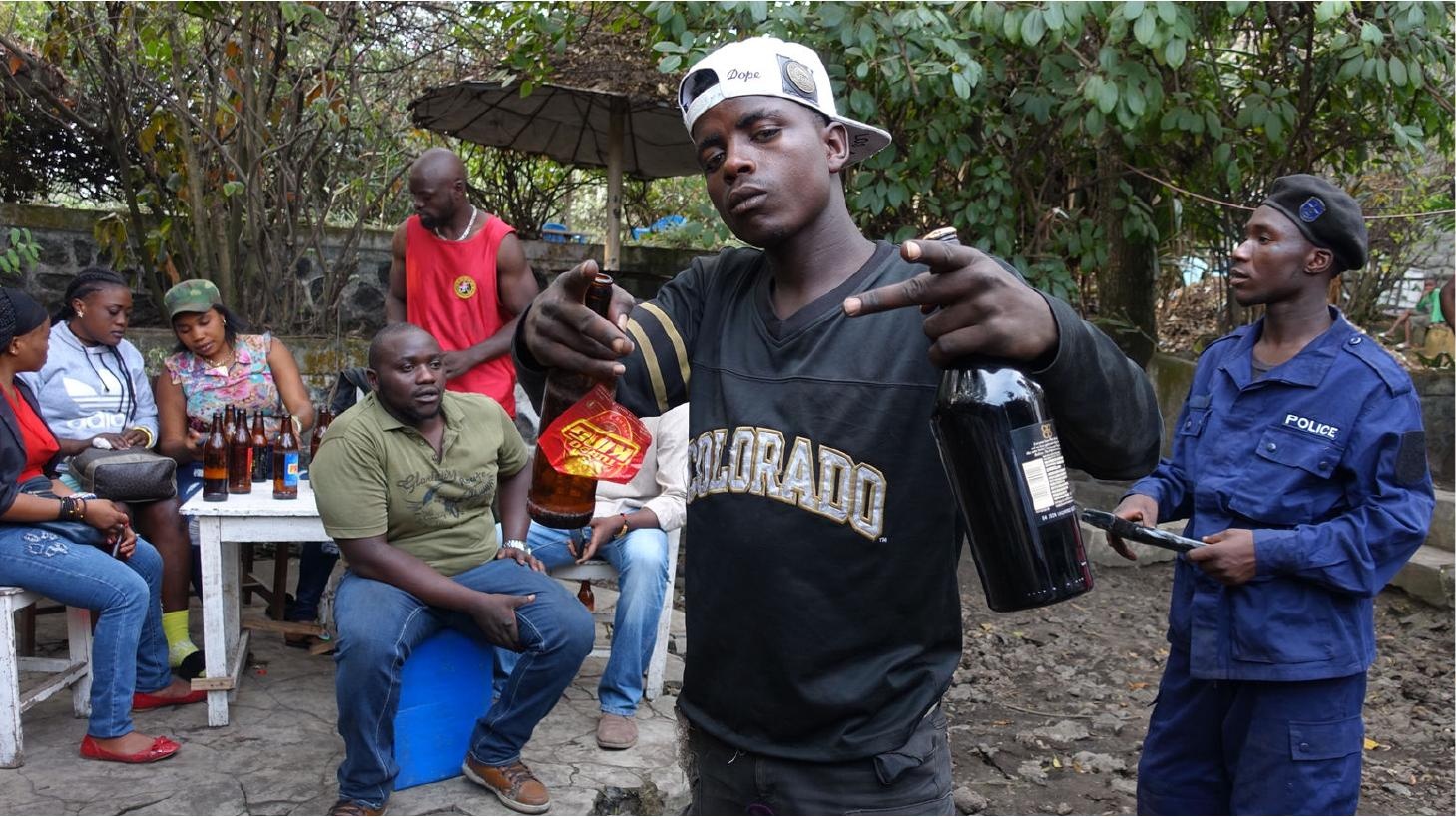

Image 3: On the set of Street Life, 06/07/2017.

the everyday life of gangs in Goma. I felt that by making this film I could get a deeper understanding of the meanings that are attributed to the figure of the maitre, the sportif and the imaginary of the martial arts movies upon which they draw. Hence, I started to collaborate with the filmmaker TD Jack Muhindo from Goma, with the goal of realizing the film Patient and his group wanted to make.

Unfortunately, this project never turned into a film. Patient fell sick, and in January 2018 he got killed, shot by a police officer in a bar. However, among the other gangs I knew, the word was already out that I was now collaborating with the filmmaker TD Jack, who accompanied me in the field with a small Sony DSC-RX100IV camera. We experimented with film methodologies as we went along, producing video materials based upon what gangs asked us to film, both fiction and non-fiction. Our most extensive co-production took place with the group Rich Gang and their leader Alain Nepanepa, alias Alino, who was during the course of my fieldwork commissioned by the Association of Congolese Drivers (ACCO) to control the taxi bus stations around the busy traffic point of Terminus. Inspired by Patient, and stressing that he too was a (tattoo) artist, Alino also proposed that we make a fiction film on his and his peers' lives as gangs and sportifs in Goma. The ultimate result was the film they named Street Life.

The first step in the realization of Street Life was working out the script. During the twoand-a-half hour drafting discussion in the group's ghetto, I remained silent. TD Jack on the other hand, as a professional filmmaker, managed the process of molding their ideas into a script - and later on the set and in the editing process, into a film. First, he asked them to think in scenes. Thereafter, they discussed each scene in greater detail. Finally on the following day - the members of Rich Gang and TD Jack discussed the preliminary dialogues and lines within each scene. Since neither Rich Gang, nor myself had any experience in making a film, TD Jack's experience as a professional filmmaker was 


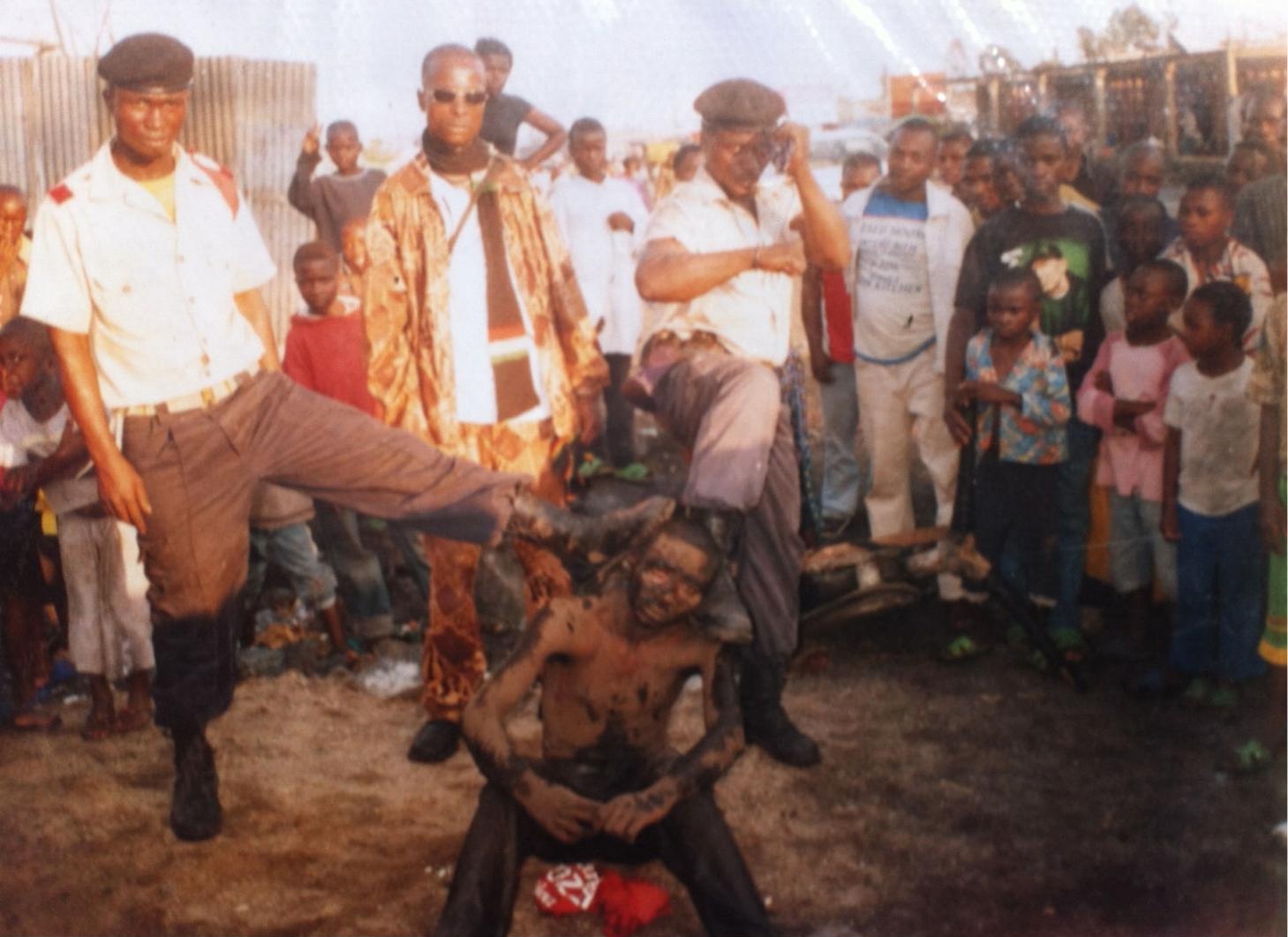

Public punishment of an alleged thief at the Virunga market (Photo Anti-gang Goma, 2008).

essential for the success of the project. He made the group think about the lead actors, the places where they wanted to film, and how they were going to visualize their thoughts and translate them into a coherent story with a beginning and an end. He also pointed out the practical limitations in time and budget, and worked out solutions for the latter. Before shooting, Alino gathered the actors he had in mind for each particular scene - people close to, or belonging to Rich gang. Once on the set, Alino and TD Jack served as the co-directors - TD Jack in his capacity as a professional filmmaker and Alino as the leader of the group upon whose lives Street Life was to be based. After every bit of editing by TD Jack, we consulted Alino and his crew to discuss whether this was what they had in mind.

\section{Street Life Performance}

The image above, in which the Anti-gang pose next to a captured thief in the Virunga, Goma's principle market, exemplifies the key role of appearance in their practices of everyday policing: the uniforms, army boots, sunglasses, Rastafari look, martial arts pose. The photo illustrates that to realize themselves as everyday policing actors, gangs rely on what Hansen (2004) - writing on a far right political party in India - refers to as the 'politics of the spectacle' and 'political performance'. Performing this type of politics 'depends on the ability to stage public performances, to use and employ a range of 
registers that can generate authority, and put the power of rumors, myth and other cultural registers to effective use' (Hansen 2004, 21). Key to Hansen's notion of performance is that it implies 'a certain styling of the self, the movement and the cause' (ibid., 23); this by a certain way of dressing, appearing, speaking, behaving and acting. Far from meaningless, these performances, through repetition and rehearsal, 'make things exist as "facts" or possibilities' and happen in the world (ibid.). 'To be someone, to enjoy respect and authority is not a given fact, but needs to be reproduced through reiterative performances of various kinds' (ibid., 27). Florence Bernault makes a similar argument, writing on different kinds of spectacles in Gabon (Bernault 2015, 754). For her, being and having has not declined into mere appearance, as Debord (1984) suggests. Instead "appearing" is essential to the possibility of being and having' (ibid.). As will become clear throughout the article, for gangs in Goma it is key to appear gang-like, sportif-like and state-like, and draw on corresponding 'repertoires' (see Hagmann and Péclard 2010) in order to shape their political subjectivity and legitimize themselves (see also Grätz 2010).

In my view, Street Life is essentially a performance of everyday kigang political performances. In From Ritual to Theatre, Victor Turner asserts that cultural performances are metacommentaries. They are stories groups tell themselves about themselves 'or in the case of theatre, a play a society acts about itself - not only a reading of its experience but an interpretative reenactment of its experience' (Turner 1982, 104). Street Life, too, is such a metacommentary. It is a film starring gangs who play themselves and re-enact their own experiences as everyday policing actors. In other words, it is a reflexive exercise in which they 'actively' - if not necessarily faithfully - mirror their lifeworld the way they see fit (ibid.). The actors carefully reflected upon how (not) to represent themselves and communicate with their audience - first and foremost, people living in Goma. It was exactly this mirroring exercise that rendered the production of a fiction film ethnographically exciting.

In sum, while my observations pointed out how performance is key in how gangs seek to carve out a political space for themselves as everyday policing actors, the making of Street Life led me to discover performance and filmmaking as a method. I thereafter made a 'discovery' similar to the one Fabian discusses in his well-acknowledged Power and Performance:

'Performance' seemed to be a more adequate description both of the ways people realize their culture and of the method by which an ethnographer produces knowledge about that culture (Fabian 1990, 18).

He made this discovery discussing the proverb 'le pouvoir se mange entier' (power is eaten whole) with a theatre group he was well acquainted with in Lubumbashi. The proverb was mentioned to him whilst having dinner with three men in Kolwezi during his fieldwork in 1985, after they offered him the chicken gizzard. If he did not want to eat the chicken gizzard he had to pass it to someone else, since, so they explained concisely: 'le pouvoir se mange entier'. Discussing the event with the theatre group on a subsequent afternoon, he was surprised by the enthusiasm with which they tried to explain the proverb to him and to each other. After which they decided to make it into to the topic 


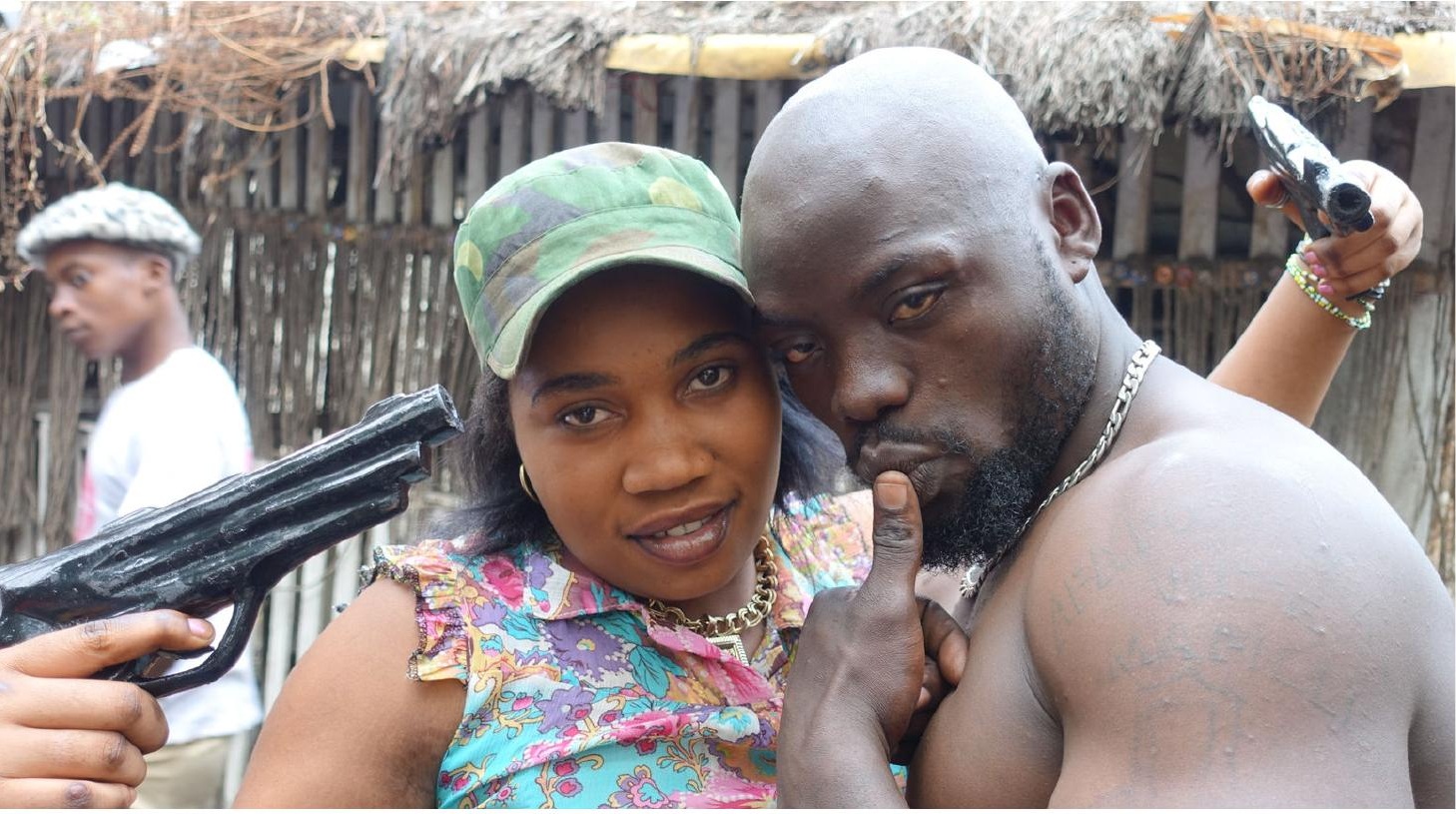

On the set of Street Life, 06/07/2017.

of their next play. That evening he wrote in his notebook: 'Here is a new ethnography the ethnographer's idea is taken up collectively discussed, cast into play, tested on a public, etc., all this [starting] from a chicken gizzard in Kolwezi' (Fabian 1990, 4). His discovery made him shift from what he called an 'informative' to a 'performative' ethnography. The ethnographer's role in the former is that of a questioner and collector of information. S/he goes to the field and collects the information, mostly by inquiring among those who - are supposed to - have it. The latter approach on the other hand turns the ethnographer into a 'provider of occasions'. It departs from the premises that some knowledge 'can be represented - made present - only through action, enactment, or performance' (Fabian 1990, 6-7; see also Boeykens 2019).

In making Street Life my role as ethnographer also shifted to that of a provider of occasions, or better a film producer. The next section deals with the question of what knowledge is made present through the performance and re-enactment of kigang life? How does it mirror everyday kigang performances?

\section{Mirroring the Everyday}

First of all, Street Life mirrors Alino's life history: growing up as a gang in Bukavu (the provincial capital of South Kivu), serving a prison sentence of four years for theft and extortion, moving to Goma once he was released, and eventually transforming himself into - in his words - a 'responsible' gang (interview Alino, Goma, 24/07/2017). The latter occurred when in 2013, after the armed group M23 retreated from Goma, the president of ACCO (the Association for Congolese Drivers) recruited Alino and his group to control the bus parking around the busy traffic point Terminus, installing order and imposing a tax of $200 \mathrm{FC}$ on the drivers who stop there.

Before Terminus was really full of thugs ... to impose law in the middle of the thugs, we had to fight. So, I fought, fought until les petits [the little ones 


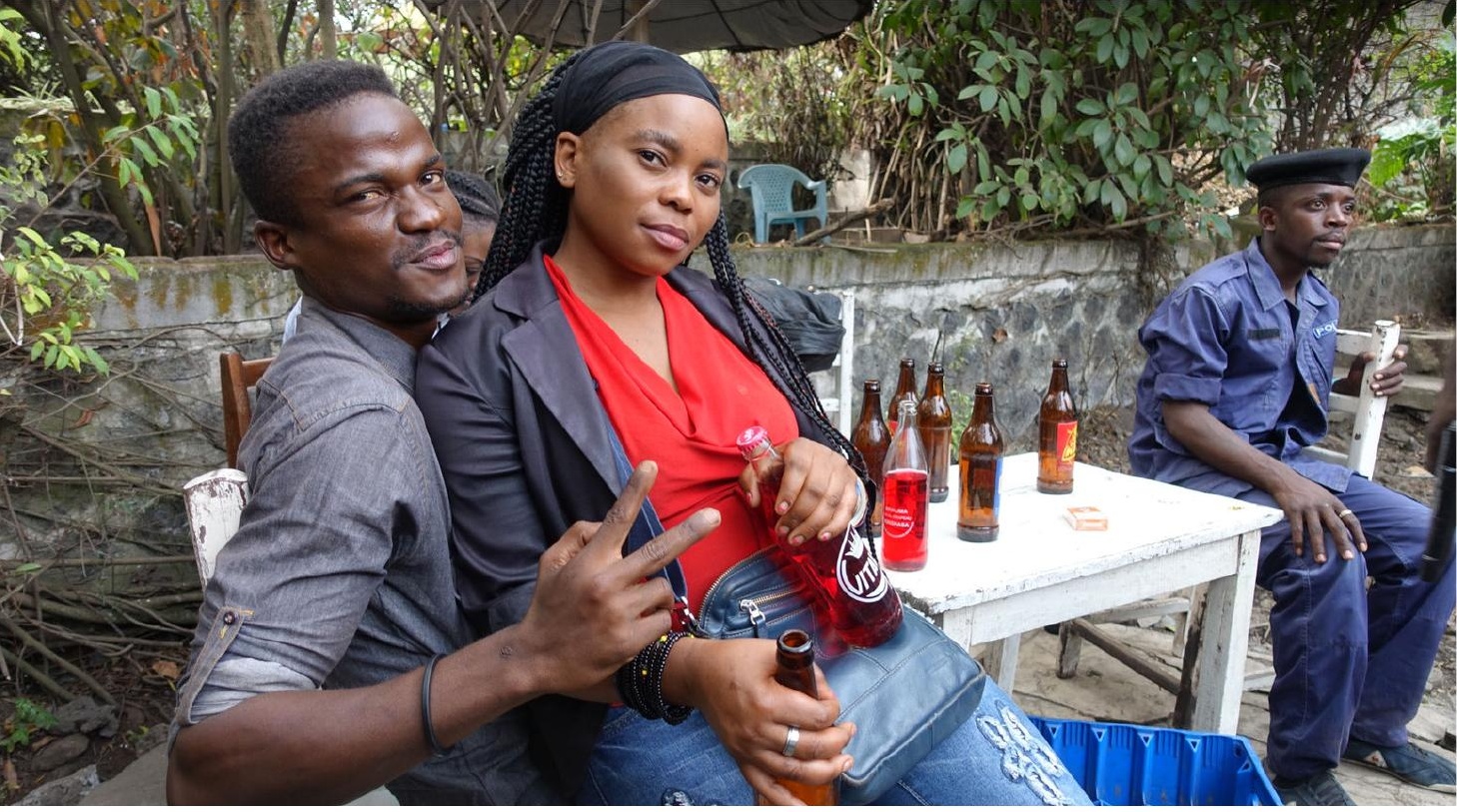

On the set of Street Life, 06/07/2017.

- referring paternalistically to his 'children', meaning his 'inferiors'] knew that I was le maître (the master). Until all I said was really respected. It put an end to the banditry that reigned at Terminus. I gave them my working hours: I will start working until 17h. If you are going to do your business, do it afterwards, when the office is closed. But I do not want to hear about theft. I have experienced that in all the stories I've gone through, in kigang life, you can do anything but not theft (interview Alino, Goma, 24/07/2017).

Since then, he argues, people in the neighborhood started to appreciate him. Although he is still a gang to be reckoned with, he now behaves responsibly.

Next to mirroring Alino's life history, Street Life captures multiple aspects of kigang everyday life: the characteristics of urban crime and policing in Goma and the ways gender and sexuality are constructed in the gang lifeworld. For the purpose of this article, however, I focus on how the making of Street Life reflects the ways in which gangs in Goma realize themselves as street authorities by relying on the politics of spectacle and political performances (Hansen 2004). In the film, they theatrically perform how they style themselves and draw upon powerful cultural and political repertoires to bolster their authority and carve out a political space for themselves in Goma's policing environment.

To clarify this argument, I suggest that you watch Street Life yourself, by scanning the QR code bellow, or let it run while you continue reading this text. ${ }^{26}$ In what follows, I will guide you through the scenes of the film textually. Although this system is far from

$26 \mathrm{https}: / /$ www.youtube.com/watch?v=CCJyS7Asp9U\&feature=youtu.be, or https://vimeo.com/ 267957647. Password: JUA KALI. 


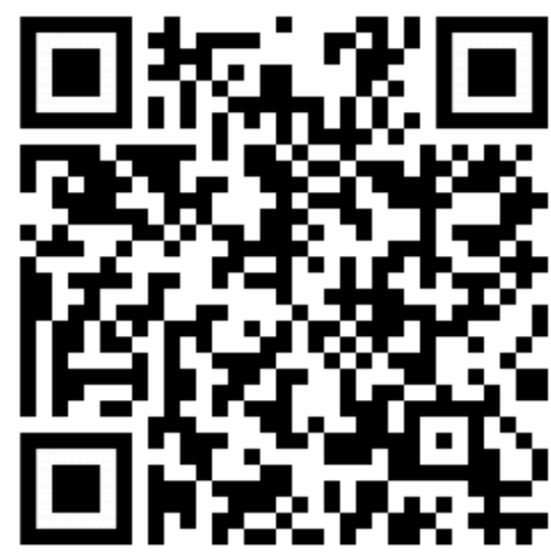

QR 1: Full movie Street Life perfect, I believe it to be necessary and appropriate for three reasons. First, Street Life is made for a Congolese, or even Gomatracien (inhabitants of Goma) audience. Therefore, some local nuances and complexities require explanation. Secondly, it turned out to be rather difficult for Alino to recruit the same actors for every production day, for the simple reason that the actors were all gangs with many things to worry about in everyday life, other than making a film. Thirdly, this medium allows me to interpret and point out the cultural and political repertoires through which gangs style themselves.

\section{Scenes 1-5: Badman, the drug trafficker, coming out of prison}

The film starts with Badman - Alino's alterego - and a fellow gang member being released from prison and picked up Badman's girlfriend and two other gang members. The crime for which he served time in prison is not mentioned. However, celebrating his release at the bar he thanks his confidant, Yannick, for getting him out after only four years of his twenty-year sentence. When asked how business is going, Yannick, who took over command while Badman was in prison, responds that business is not bad. Yet Yannick mentions how lately the commune (the municipal administrative authority) disturbs them a lot. But now that Badman is out, he asserts, 'things will go well again'.

In the third scene, Badman and his girlfriend make love in a hotel, then go dancing in a club. The scene ends with Yannick being robbed and beaten, and taken to the hospital by his friends. The fifth scene takes place at Badman's house. On the left one sees a big marijuana plant, with people ginning the grains from the harvested weed in the background. Meanwhile, Badman and his confidant are sitting under a parasol smoking an enormous joint and drinking strong liquor. Two women and ghetto owners enter to buy fresh supplies of marijuana. One of the business women says to Badman that he does not show himself anymore, to which he responds that since he got out of prison, he is not going to be involved in his former (criminal) activities. He reassures those present, however, that now that he is out, marijuana trafficking will go well again - which he distinguishes from his 'former (criminal) activities' (cf. infra.). While he was in prison the army commander in a - non-specified - village outside Goma, where Rich Gang sources its marijuana, was replaced by someone who does not let the weed pass to Goma. This has caused a shortage of supplies. Badman persuades the purchasers to share the small quantity available, and promises them to deal with the broader situation in two or three days.

In sum, in the first five scenes Alino presents himself as a maitre, or a patron amongst gangs; a theme that resurfaces throughout the film. He theatrically draws upon the ganglike cultural repertoire of smoking marijuana which - as Gondola (2016) also argues for the yankees and bill movement in the colonial Kinshasa of the fifties - provides a strong sense of identity and belonging amongst gangs in the city. Although he smokes a lot of 
joints in everyday life, for the movie this aspect is highlighted and literally 'enlarged' by rolling a joint of an absurdly large size. Moreover, in the film gangs theatrically stress that they are important marijuana traffickers. When, during the making of the script TD Jack asked them why they absolutely wanted to show this aspect in the movie, one gang member responded:

It is to show that this is our only source of income, so that they their audience of people in Goma do not suspect us of other things. To show that we are not into stealing, that we are not harming people (recording of script drafting session for Street Life, Goma, 21/03/2017).

\section{Scenes 6-7: Badman as a maître \& sportif}

In the sixth and the seventh scene, Alino deploys the cultural repertoire of being sportif (trained in the martial arts), infused with an imaginary of the martial arts movie genre of Bruce Lee and Jean Claude van Damme. Badman visits his temple and when he catches his disciples not taking their training seriously, he gives them a reprimand. For their part, Badman's disciples respectfully salute him saying 'osu mzee'.27 After letting them do some push-ups as penance for messing around, he gives them a demonstration of self-defense moves and shows them how to catch a thief. Afterward, they all go to wash themselves in the lake. One of the actors, taking advantage of his one and only speaking line in the film, accentuates his sportif nature by twitching one of his peck muscles up and down. The following scene shows yet another work-out of bare-chested gangs lifting weights. After this work-out, Badman is pleased and addresses his petits (little ones) in an almost military fashion, stating that they are now physically fit and capable of blocking a thief. Therefore, he evaluates, they are ready to go sur terrain (into the field, meaning securing the neighborhood). What we see here, through action and discourse, is the crucial importance of being sportif as part of being successfully gang.

\section{Scene 8- 9: Badman \& the chef de quartier collaborating to install order in the neighborhood}

The next scene starts with Badman managing business at his house, asking his confidants how the sports trainings are developing and how things are going with the marijuana supply. His confidants confirm that the sports trainings are going well and that the weed will arrive any minute now. At that moment, the chef de quartier (the administrative authority on the neighborhood level) and his wife come in, asking for Badman's help in dealing with the Bazulu, a gang of thieves who are terrorizing the neighborhood. According to the neighborhood chief, they have gone too far by robbing one of his neighbors who works for MONUSCO (the local UN peacekeeping mission) of some work papers, his badge, his laptop, and a Motorola (portable radio). Badman shows that he knows the problem intimately, stressing that Rich Gang have already received numerous reports about the Bazulu, and have even been in an altercation with them in which they chased and caught some of the group. The chef de quartier praises Badman. Unlike the police who are often arrive too late to intervene, Badman and his group help him a lot. Badman agrees to help, but insists that his men need protection from the police. Firstly, he argues, because otherwise if Rich Gang catch someone, he will

${ }^{27}$ Osu is an often-used karate term. Mzee is a Kiswahili word to respectfully refer to elders. 
be quickly released. And secondly because they are sportifs, who simply use their physical strength to block a person. An intervention of the police afterwards, he argues, is necessary. As Badman accompanies the chef the quartier and his wife to the door, the marijuana arrives, brought in by motorcycles decorated with large American flags.

When I asked Alino about these flags, he answered that in the USA there 'are also people like us, but they have guns and more money.' Apart from several manifestations of this gang-like repertoire, it is clear that in the former scenes, Alino and his gang strongly elaborate on their relationship with the state. They seek to convey that because they are gangs - and therefore intimately know Goma's gang world -, they are well placed to help the chef de quartier, the police and other state authorities to instill order in the neighborhood. When the chef de quartier denounces the police for not functioning properly, Alino stresses that they need police protection to carry this mission to a fruitful end. In other words, they emphasize that they are not operating in an 'anti-state' framework. On the contrary, through multiple scenes in the movie, Alino and his colleagues illustrate how they insert themselves within state networks to bolster their own authority. 28

\section{Scene 10-11: mère Mogroso's Ghetto}

In the next scene, mère Mogroso who is one of the women running a ghetto is picking up her share of the weed, accompanied by her child and chauffeured by a driver in a big Toyota jeep. The following scene takes place at her Ghetto. Four gangs are playing cards at the table when Mosa Swing, one of the Bazulu gang members who robbed the employee of the MONUSCO enters and tries to sell the Motorola they had stolen from the latter. Before negotiating the price with mère Mogroso, he asks her to offer some weed and cigarettes to the gangs playing cards. This is a common practice to make sure they won't cause him trouble, since they are now witnesses of the crime he and his friends committed. Meanwhile, mère Mogroso calls for Yannick of Rich Gang, who is inside. He takes her aside where the others cannot hear them and explains that Badman and the chef de quartier are looking for the thieves that stole the MONUSCO goods. They agree to call Badman, and ask him to come with des hommes fort (strong men) to arrest Mosa Swing. In return, mère Mogroso asserts that for her collaboration, MONUSCO needs to give her some money. Badman, three of his gang members, the chef the quartier, accompanied by a police officer arrive and arrest Mosa Swing as well as the gangs playing cards. The police officer is dressed in a private security company uniform, since we did not manage to get our hands on an official police uniform that day. The scene ends by the chef the quartier thanking Badman for retrieving the stolen goods.

Again, the repertoire of being gang is explicitly deployed in these scenes, as is the importance of the position of a gang within the gang landscape. As a maitre and patron amongst gangs, Alino is able to solve the blockage of the marijuana supply. Moreover, since as gangs they are well-connected with the ghettos around the city - which are hotspots for the criminal economy in Goma - Badman and his people are able to find the Bazulu thief wanted by the chef de quartier.

${ }^{28}$ For further elaboration of this argument, see Hendriks (2018). 


\section{Scene 12-13: Le grand Zulu}

The following scene presents the 'bad guy' or anti-maitre: le grand Zulu. Dressed in military-style camouflage, he drinks beer together with two members of his gang (the Bazulu). Another gang member, dressed in a karate outfit, guards the gate of the compound. A young woman presents herself at the gate and asks to see Zulu. In a military-like gesture, the guard passes the message to a trustee of Zulu's, who in turn agrees to see the young woman. Sitting next to Zulu, she informs him that Badman beat up his petits (little ones) the other night in a bar where she had gone dancing. During their conversation, an older man knocks on the door. It appears to be a patron who collaborates with Zulu, coming to offer him a job. He wants Zulu to bring him four virgin girls. Zulu accepts, asking 10,000 dollars per girl. After the meeting, one sees le grand Zulu weightlifting and hitting the punching ball in his temple to the tune of Bob Marley's One Love, accompanied by the guard from the former scene, still in kimono (karate outfit). Two young women are watching them. At the end of the training, one of them looks on jealously as Zulu takes the other woman upstairs to make love. Then the guard comes and takes her upstairs, as well.

Similarly, for instance, to the bad guy (Han) in Bruce Lee's Enter the Dragon (and a number of other martial arts movies), le grand Zulu is involved in prostitution and women trafficking. The scene also mirrors Alino's life when he was still a bandit, before he became - in his words - a responsible maître. Back in his bandit days, Alino and his colleagues charged sex workers up to ten dollars for hassling on the streets and in the bars of their neighborhood. Moreover, like Mosa Swing in the film, on occasion Alino and his group stole supplies from MONUSCO vehicles carrying food, uniforms etc., as they passed early in the morning on their way to the frontlines (interview Alino, Goma, 24/07/2017). Lastly, the scene makes clear that the Bazulu also style themselves by drawing upon gang-like as well as, state-like and sportif-like repertoires. Women in the film are presented in a way that confirms the gangs' hyper-gang-masculinity (Gondola 2016).

\section{Scene 14-16: Providing security and protection (rackets)}

The next scene shows how Rich Gang collects money, in return for their 'protection' services around the traffic point Terminus, asking 200FC from every shop and ambulant vendor. All collections are carefully noted down in a book. Persuading vendors to pay, the gang members argue 'you see there are no thieves here, no police, it is us that do security;' 'it is our right to take this money from you;' 'you forget that we never stole from you, because we are Anti-gangs.' While some of the vendors pay immediately, others refuse. One of them only pays reluctantly after they threaten to take down the parasol under which she sells her goods. When another young woman refuses, they 'confiscate' one of her shirts. To show that they are no brutes however, they return it to her shortly afterwards, making her promise that she will pay the next day. To show that they really provide protection in return for the collected 'taxes', the following scene shows a member of Rich Gang catching a thief who stole a woman's bag at the bus station. The film ends, like all good martial arts movies - in the style of Jean-Claude van Damme and Bruce Lee - with a fight between the good and the bad guys. After Rich Gang has beaten the Bazulu, the police make a spectacular entrance and arrest the latter.

In sum, Street Life mirrors Rich Gang's everyday political performance realizing themselves as an everyday policing actor in Goma. It is important to note that the mirror the film 
holds up to the group's lifeworld transforms and magnifies rather than faithfully reflecting their image (Turner 1982, 104-5). The film deliberately emphasizes the importance of certain activities - such as practicing martial arts and stopping thieves, and certain stages - such as the temple and the ghetto. It also theatrically highlights particular aspects of kigang life, for example by showing characters rolling a huge joint or guarding a gate in karate garb - neither of which they would do in everyday life. However, in this distortion of their image, Rich Gang stress the state-like, gang-like and sportif-like repertoires that form the basis for their everyday political performance.

As with this everyday political performance, Street Life seeks to communicate a message to their target audience, people living in in Goma's popular neighborhoods. In both real life and movie performances 'they call upon tropes, symbols and metaphors presumed to be well understood' by this audience (Strauss and O'Brien 2007). The difference from 'real life', however, is that providing them the occasion to make a film about their lives, offered them a platform where they were more in control of things, had 'the right to do and say anything' (Rouch 1958) and reflect on what they seek to communicate and how to deconstruct their message into scenes, stages and roles. During the drafting of the script, Alino explained:

It needs to be a film with a clear message, that teaches a lesson. We have to show that we were bandits before, and regularly got arrested. But because of all this suffering, we grew up, left these bavures [imperfections, mistakes] behind and found jobs. This story of bus stations. We have to show that I have changed. I have a job now, and this job, I do not only do for ACCO, but for everyone. People of the neighborhood and those who live around know that I made this choice [working for ACCO] and that I have changed. But without forgetting that I was someone [a bandit] before, but I have changed and started to educate others (Alino in recording of script drafting discussions for Street Life, Goma, 21/03/2017).

In short, the message that Rich Gang want to communicate through the film is that because they were previously 'bad people', because they are gangs and sportifs trained in the martial arts, they can be 'of service to the population' and help the government bring peace and order to their neighborhood. Furthermore, their skills and experience allow them to install discipline and create jobs for youths who might otherwise commit crimes (ibid.).

\section{Ethnographic Reflections: Street Life as a Route to Knowledge Production}

In the former section, I have tried to demonstrate that political performance is key to how gangs realize themselves as everyday policing actors. As they like to say, 'We are living [martial arts action] movies.' The making of Street Life offered Rich Gang a stage to re-enact kigang life as a movie, and offered me as an ethnographer a route to produce knowledge about their everyday political performance. This leads us back to Fabian's proposition (cf. supra) that performance can be both a means for people to realize their culture, and a method for the ethnographer to produce knowledge about that culture 
(Fabian 1990). The crucial question now is what happens along the way, and where does this route take us in terms of ethnography?

Methodologically, it took me towards a more collaborative style of doing ethnography 'ethnography with, not of (Fabian 1990, 43; Boeykens 2019; Mai 2016). The actors of Street Life actively participated in bringing this project to fruition. They wanted to realize this film and took initiative. This for the simple reason that it would leave them with something concrete other than the vague promise of $\mathrm{PhD}$ being written about them i.e. their own martial arts action movie. Once the film was finished, they received it on a USB stick, which they then distributed themselves in shops and ghettos in and around their neighborhood. Their active involvement and motivation to play their own roles in front of a camera offered me, in Pype's words, 'a privileged vantage point to observe' (Pype 2012, 21) the performative aspects of kigang life.

Furthermore, by making this film I shifted in the direction of what Fabian has called performative ethnography - 'the kind where the ethnographer does not call the tunes but plays along' (Fabian 1990, 19). To some extent, I ceded control over the data-gathering process. It was no longer me deciding where to focus, which questions to ask, who to meet and what to see. It was more Alino and the rest of Rich Gang presenting themselves the way they saw fit. My role as an ethnographer shifted from that of observer and questioner to that of a film producer and 'provider of occasions' (Fabian 1990, 7). I must admit that this made me feel anxious at times. Some days, we spent several hours waiting for the actors to show up, which made me wonder if I was not just wasting time I could otherwise have spent on observations and interviews, basically on doing 'my job.'

In short, engaging in this filmmaking ethnographic experiment shifted my positionality as an ethnographer and transferred greater control of the fieldwork practice to the research subjects. I am not trying to formulate an ethical argument about this way of doing ethnography being morally superior to that practiced by an ethnographer who comes in, extracts information and leaves. That said, realizing Street Life was indeed a nice way to give something back to my research participants. To be clear, assuming that letting them call the tunes guarantees a more equal ethnographic encounter can be rather risky. The issue is of an epistemological nature (Fabian 1990, 5), as it touches on questions of how the making of a fiction film together with gangs in Goma enables us to know, or how knowledge is produced by a fictional re-enactment of people's everyday political performance.

Like the presence of the observing and questioning ethnographer, Jean Rouch stresses in this regard, that 'the camera opens a window' (Rouch 2003). In the process of filming, provoking people to act and re-enact their own and familiar roles in front of a camera, people reveal themselves and what they find significant. In these revelations, meanings emerge (Feld 2003, 16). This is what Rouch would call, the 'cinematic truth' (Eaton, 1979; Sjöberg, 2008). This is exactly what happens in Street Life when Alino and Rich Gang theatrically mirror certain powerful cultural and political repertoires, significant events in their lives and the imaginaries upon which they draw. Although these are fictional re-enactments, they convey fundamental aspects of kigang life, and the ways in which gangs shape their political subjectivity. 


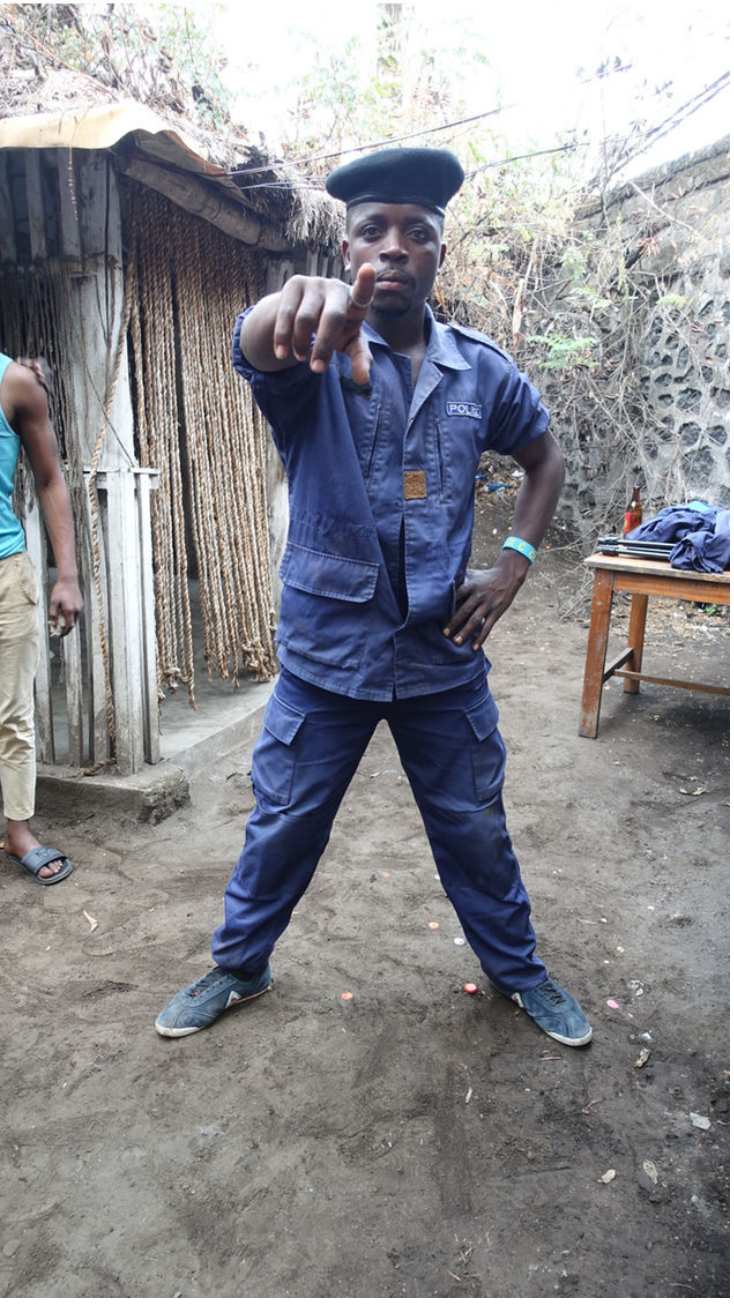

On the set of Street Life, 06/07/2017.

In terms of ethnographic representation, it is important to note that Street Life requires an accompanying interpretative text - different from, for example, Jean Rouch's ethnofictions and De Boeck's Cemetery State. Whereas the ethnographer Jean Rouch remains the author and director of his films, in the making of Street Life I took up the more passive role of producer and facilitator. ${ }^{29} \mathrm{My}$ job as an ethnographer however is to do my own little performance - of writing this article and a $\mathrm{PhD}$ monograph - around their performance making Street Life. In other words, Street Life does not have the status of ethnographic knowledge in itself, but should rather be understood as a route to knowledge production and a tool to imagine and encounter the lifeworld of gangs as everyday policing actors in Goma (Pink 2013, 39). Although they allowed me to, I am hesitant to make the film available online, or show it without an accompanying oral or textual interpretation, since viewers might see the stereotype of the violent African subaltern confirmed in it. The job of an ethnographer, then, is to interpret why subjects portray themselves the way they do.

Notwithstanding, I remain convinced, as stated in the beginning of this article, that you need to see it! (to better understand it). Film as a medium has the potential of 'showing' the vitality, and demonstrating the performative and aesthetic aspects of social life in ways that 'the dead space of the printed page' often cannot (Stoller 1992, 99). To take performance seriously, should mean to take the visual - and other senses - seriously, and incorporate them in our academic work.

\section{Conclusion}

By making the film Street Life, we - Alino, Rich Gang, TD Jack and me - have tried to make the movie that gangs in Goma often claim they 'live'. This offered participants a stage where they had 'the right to do and say anything' (Rouch 1958). The result is a

\footnotetext{
${ }^{29}$ At the moment of writing I have received funds to rework the film Street Life together with the Congolese cineaste TD Jack and the Belgian cineaste Pieter De Vos into a critical film/ documentary that can stand on its own, without accompanying text.
} 


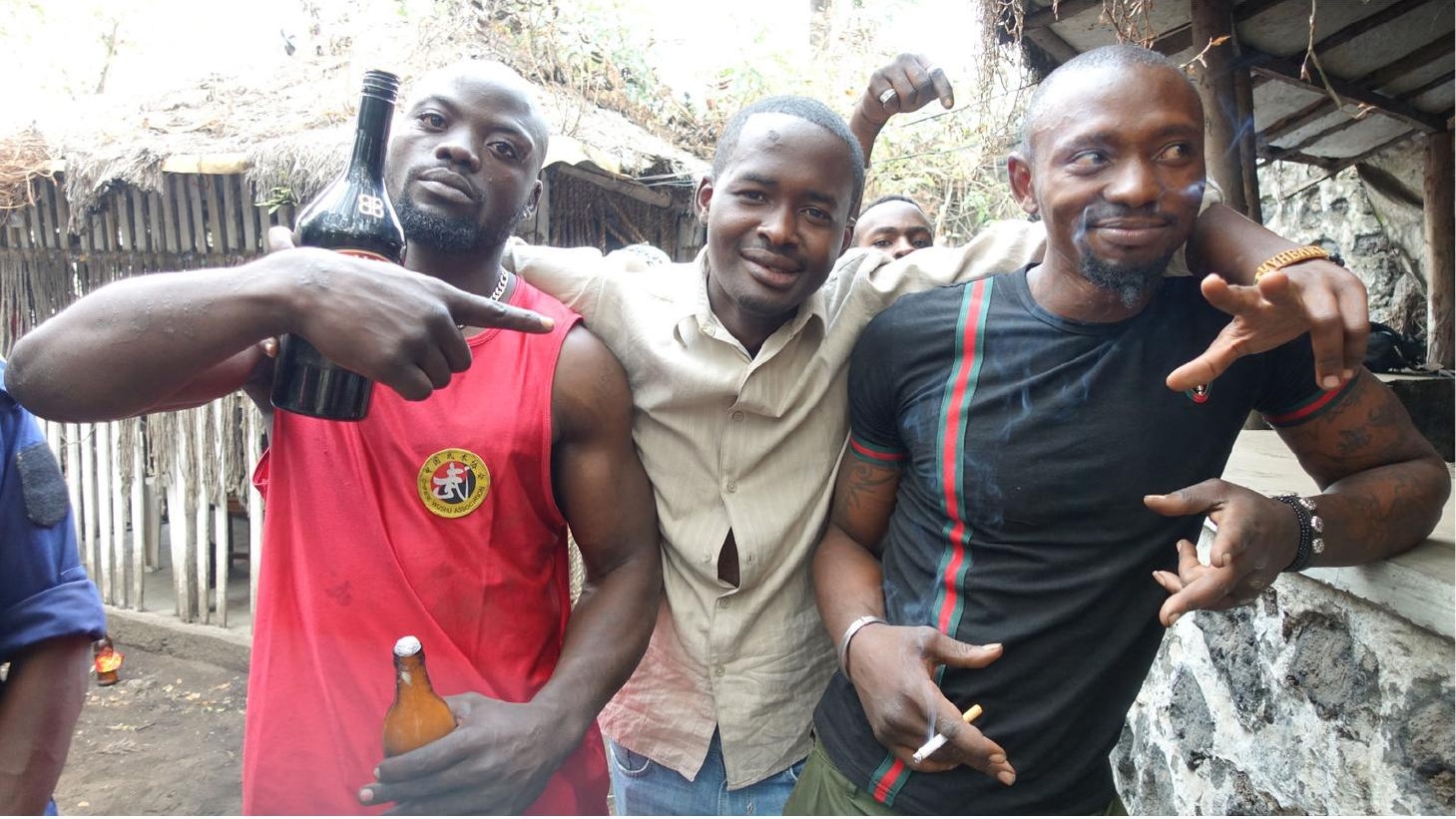

On the set of Street Life, 06/07/2017.

commentary on their lifeworld, and re-enactment of their everyday political performance carving out a political space for themselves. This political space is located somewhere in between the 'gangs', the 'state' and the 'populace' in the complex urban environment of the city of Goma in eastern Congo. Street Life shows very well how gangs self-style and realize themselves as everyday policing actors aiming to provide protection and order in the streets of Goma, by theatrically accentuating powerful cultural and political repertoires - sportif-like, gang-like and state-like - presumably well understood by their audience; people living in Goma's popular neighborhoods. The message they seek to communicate is one of becoming: because we are gangs, trained in the martial arts, we can be engaged in protecting Goma's inhabitants against the everyday crime of the maibobo (street children) and other gangs. They claim not to be anti- or against the state, but rather seek to help the police and the municipal authorities bringing order and security to the neighborhoods.

Because of the above, I argue that Street Life produces knowledge about the political performance of gangs. 'The camera opens a window' where people reveal themselves and meanings emerge (Rouch 2003). On this route to knowledge production, my positionality as a researcher and way of engaging with ethnography shifted towards a collaborative and more performative ethnography. Rather than a 'collector of information', calling the tunes, I became a producer or 'provider of occasions', playing along (Fabian 1990).

Moreover, the medium of film offers exciting - but still underutilized - avenues for ethnographic representation. Instead of putting sensory, performative and affective experiences into discursive statements, sometimes it is better to allow others to just see it! 
Bernault, Florence. 2015. "Aesthetics of Acquisition: Notes on the Transactional Life of Persons and Things in Gabon." Comparative Studies in Society and History 57 (3): $753-79$.

Boeykens, Tessa. 2019. "Exile, Return, Record: Exploring History \& Community Defense through Participatory Filmmaking in 'Post-Conflict' Guatemala." Fournal of Extreme Anthropology.

Büscher, Karen. 2011. "Conflict, State Failure and Urban Transformation in the Eastern Congolese Periphery.” PhD, Gent: Ghent University. https:// biblio.ugent.be/publication/2092391/file/4335807.

Buur, Lars, and Steffen Jensen. 2004. "Introduction: Vigilantism and the Policing of Everyday Life in South Africa." African Studies 63 (2): 139-52.

De Boeck, Filip. 2014. "Cemetery State.” In Global Prayers: Contemporary Manifestations of the Religious in the City, 314-20. Lars Müller Publishers.

Debord, Guy. 1984. Society of the Spectacle. Detroit, Mich: Black \& Red, U.S.

Eaton, Nick. 1979. Anthropology-Reality-Cinema: Films of Jean Rouch. Edited by Mick Eaton. First Edition edition. London: British Film Institute.

Fabian, Johannes. 1990. Power and Performance: Ethnographic Explorations through Proverbial Wisdom and Theater in Shaba, Zaire. Madison, Wis: University of Wisconsin Press.

Feld, Steven. 2003. "Editor's Introduction.” In Ciné-Ethnography, 400. Minneapolis: University of Minnesota Press.

Gondola, Gh Didier. 2016. Tropical Cowboys: Westerns, Violence, and Masculinity in Kinshasa. Bloomington: Indiana University Press.

Grätz, Tilo. 2010. "Dévi \& His Men: The Rise \& Fall of a Vigilante Movement in Benin." In Domesticating Vigilantism in Africa, edited by Tilo Grätz and Thomas G. Kirsch, 79-97. New York: James Currey.

Hagmann, Tobias, and Didier Péclard. 2010. "Negotiating Statehood: Dynamics of Power and Domination in Africa." Development and Change 41 (4): 539-62. https://doi.org/10.1111/j.1467-7660.2010.01656.x.

Hansen, Thomas Blom. 2004. "Politics as Permanent Performance: The Production of Political Authority in the Locality." In The Politics of Cultural Mobilization in India, edited by John Zavos, Andrew Wyatt, and Vernon Hewitt. New Delhi: Oxford University Press.

Hendriks, Maarten. 2018. "The Politics of Everyday Policing in Goma: The Case of the Anti-Gang." Journal of Eastern African Studies 12 (2): 274-89. https://doi.org/ 10.1080/17531055.2018.1459976.

High, Gasey. 2010. "Warriors, Hunters, and Bruce Lee: Gendered Agency and the Transformation of Amazonian Masculinity." American Ethnologist 37 (4): 753-70. https://doi.org/10.1111/j.1548-1425.2010.01283.x.

Jensen, Steffen. 2008. "Policing Nkomazi: Crime, Masculinity and Generational Conflicts." In Global Vigilantes, edited by David Pratten and Atryee Sen, 47-68. New York: Columbia University Press.

Kyed, Helene Maria. 2018. "Street Authorities: Community Policing in Mozambique and Swaziland." PoLAR: Political and Legal Anthropology Review 41 (S1): 19-34. https://doi.org/10.1111/plar.12251.

Loizos, Peter. 1993. Innovation in Ethnographic Film: From Innocence to Consciousness, 1955-85. Chicago: The University of Chicago Press. 
Mai, Nicola. 2016. "Assembling Samira: Understanding Sexual Humanitarianism Trough Experimental Filmmaking." AntiAtlas fournal 01: 1-15. http://rgdoi.net/ 10.13140/RG.2.1.3492.1369.

Olander, Eric. n.d. "The Enduring Popularity of Chinese Kung Fu Movies in Africa." The Chinafrica Project. Accessed May 23, 2019. https:// chinaafricaproject.com/podcast-china-africa-kung-fu-bruce-lee-movies-cobusvan-staden/.

Pink, Sarah. 2013. Doing Visual Ethnography. 3 Revised edition. Los Angeles: SAGE Publications Ltd.

Pype, Katrien. 2012. The Making of the Pentecostal Melodrama: Religion, Media and Gender in Kinshasa. 1st ed. Berghahn Books.

Rouch, Jean. 1958. Moi, Un Noir. Ethnofiction. Icarus Films. https:// www.youtube.com/watch? $\mathrm{v}=\mathrm{rDmHpZcXee0.}$ 2003. Ciné-Ethnography. Edited and translated by Steven Feld. Minneapolis: University of Minnesota Press. https://www.upress.umn.edu/book-division/ books/cina-c-ethnography.

Sjöberg, Johannes. 2008. "Ethnofiction: Drama as a Creative Research Practice in Ethnographic Film." Fournal of Media Practice 9 (3): 229-42. https:// www.tandfonline.com/doi/abs/10.1386/jmpr.9.3.229_1.

Stoller, Paul. 1992. The Cinematic Griot: The Ethnography of Jean Rouch. Chicago: The University of Chicago Press. https://www.press.uchicago.edu/ucp/books/book/ chicago/C/bo3641129.html.

Strauss, Julia G., and Donal Gruise O'Brien. 2007. "Introduction.” In Staging Politics: Power and Performance in Asia and Africa, edited by Julia C. Strauss and Donal Cruise O'Brien, 1-14. London: I.B.Tauris.

Turner, Victor. 1982. From Ritual to Theatre: The Human Seriousness of Play. New York, NY: PAJ Publications.

Maarten Hendriks is a $\mathrm{PhD}$ Fellow at the Ghent University, his research ethnographically focusses on practices of everyday politics in Goma, the provincial capital of North Kivu (DRC). More precisely his PhD research examines how gang and Anti-gang subjectivities are shaped in the city. Keywords: Vigilantism, Violence, Visual Ethnography, Participative Video, DRCongo, Goma. This research was funded by FWO (Flemish Research Fund). 